
ПОСТТРАВМАТИЧНЕ ЗРОСТАННЯ ПІДЛІТКІВ:
ДО ПОБУДОВИ ТЕОРЕТИЧНОЇ МОДЕЛІ

\title{
THE POST-TRAUMATIC GROWTH OF ADOLESCENTS: CONSTRUCTION OF THE THEORETICAL MODEL
}

\begin{abstract}
у статті викладено результати теоретичного аналізу структури й змісту посттравматичного зростання як самостійного психологічного френомена, представлено теоретичне обгрунтування схеми дослідження посттравматичного зростання в підлітків. Показано, що в структурі посттравматичного зростання підлітка важливе місце займають вікові характеристики. Базовими компонентами посттравматичного зростання підлітків є ідентичність особистості, тимчасова перспектива, реслексія, відносини 3 людьми, иіннісно-смислові орієнтації. Провідною тенденцією посттравматичного зростання є побудова часової перспективи й трансформація образу Я. У результаті теоретичного аналізу було виділено психологічні конструкції, пов'язані з позитивною динамікою переживання підлітками психотравмувальної події, які об'єднані в такі блоки: особистісний блок, блок відносин та екзистенціальний блок. Особистісний блок пов'язаний із когнітивними уявленнями про себе й схемами самості, які фрормують Я-концепцію та ідентичність особистості, а також із рефлексією та побудовою часової перспективи. Блок відносин містить зміни характеру взаємовідносин, підвищення довіри до навколишніх людей. Екзистенціальний блок відбиває зміну фрілософрії життя, пріоритетів і ціннісно-смислових орієнтацій таким чином, що підліток вчиться цінувати життя та відрізняти важливі речі від дрібниць. Підсумком посттравматичного зростання є формування позитивної ідентичності, нової життєвої перспективи, транссрормація иінностей і зміна відносин із людьми. Подальші перспективи пов'язані з емпіричною перевіркою такої моделі, яка дозволяє визначити не тільки рівень посттравматичного зростання в підлітків, його зміст і структуру, а також специоріку в різних життєвих обставинах.

Ключові слова: посттравматичне зростання, психічна травма, теоретичні моделі посттравматичного зростання, підлітковий вік.
\end{abstract}

5208.2021 .23 .28

\section{Сазонова I.B.}

аспірант

Київський національний університет

імені Тараса Шевченка
The article presents the results of the adolescents' post-traumatic growth (PTG) theoretical analysis. PTG means the ability to rise a higher level of personal development by overcoming the consequences of a traumatic event. Moreover, such changes are easier for young people and adolescents because of their cognitive flexibility. In addition, the phenomenon of PTG in this age group has been little studied, which, not least, was the reason for our choice. The article's aim is the building of theoretical model for studying PTG in adolescents. A thorough analysis of the literature allowed us to identify three basic blocks of PTR in adolescents: the personality block, the relationship block, and the existential block. The first one is related to cognitive self-concepts and self-schemas that shape the self-concept and personality identity. It also includes building of a temporal perspective, which is closely related to the reflection that differs from rumination, because reflection focuses on finding solutions to a problem, when rumination focuses on made mistakes. The second block includes relationships with people that PTG can strengthen and make mature, rather than destroy, as is the case with PTSD. The sphere of communication initially occupies an important place in the life of an adolescent, and PTG makes an adolescent to value communication with friends and relatives more, to show empathy. The third block reflects spiritual growth, changes in the philosophy of life, priorities and values in such a way that the adolescent learns to value life and distinguish important things from less important. The result of PTG is the formation of a positive identity, a new life perspective, transformation of values, and changes in relationships with people. Further prospects are associated with the empirical verification of this model, which makes it possible to determine not only the level of PTG, but also its content and structure, as well as the its specifics in various life circumstances. Key words: post-traumatic growth, mental trauma, theoretical models of PTG, adolescence. positive changes, psychological dimensions of PTG.
Постановка проблеми. Останнім часом активно розробляється концепція «посттравматичного зростання». Посттравматичне зростання (далі - ПТЗ) - це переживання позитивних змін у результаті зіткнення зі складними життевими кризами, до яких відносять серцево-судинні захворювання, злоякісні новоутворення, озброєні зіткнення, втрату близьких, втрату житла, авіакатастрофи тощо [14, с. 1]. Велика кількість різноманітних кризових та екстремальних життєвих ситуацій, варіативність індивідуальних проявів ПТЗ, наявність руйнівних особистісних переживань одночасно з позитивною динамікою постають як джерело принципових труднощів теоретичного осмислення феномену [12]. Виходячи із цього положення, ми вважаємо цілком виправданим застосування концепції посттравматичного зростання у випадках травмування підлітків у зв'язку зі збройним конфліктом на Сході України (втрата близьких, втрата житла, вимушене переселення, розрив відносин із друзями й родичами й інше).

Аналіз останніх досліджень і публікацій. Дослідження посттравматичного зростання (ПТЗ) проводяться психологами, починаючи з середини 1990-х рр. У дослідженнях використовується широкий діапазон ознак / вимірювань із позицій різних теоретичних моделей ПТЗ, серед яких функціонально-дескриптивна модель R.G. Tedeschi й L.G. Calhoun; особистісно центрована модель S. Josef; біопсихо- 
соціальна модель М. Christopher; психолого-філософська модель R. Papadopulos, модель позитивної трансформації особистості в умовах екстремальності М.Ш. МагомедЕмінова, модель «Дволикий Янус» А. Маркера й Т. Цольнера тощо.

Натепер найбільше викладення отримали дві теоретичні моделі: функціонально-описова модель, розроблена Р. Тедескі й Л. Калхуном, та особистісно центрована модель, запропонована С. Джозефом [12].

Функціонально-дескриптивна модель посттравматичного зростання була розроблена в руслі соціально-когнітивного підходу до посттравматичного стресу, сформульованого американською дослідницею Р. Янофф-Бульман. Особливе значення для цієї теоретичної моделі отримало поняття «світ припущень» (assumptive world). Автори функціонально-дескриптивної моделі розглядають ПТЗ із позицій когнітивних переоцінок дотравматичних уявлень про світ і реконструкцій «світу припущень» [14].

Тедескі й Калхун виявили п'ять життєвих сфер, в яких може проявитися посттравматичне зростання: (1) знаходження нових можливостей; (2) відчуття зрослої особистісної сили; (3) велика близькість у стосунках із людьми, вдячність до інших; (4) трансформація цінностей, усвідомлення цінності життя в цілому; (5) інтерес до духовної сторони життя, збагачення екзистенціальної складової частини життя [14].

Особистісно центрована модель С. Джозефа базується на теоретичних поглядах К. Роджерса й розглядає ПТЗ як процес когнітивної акомодації травматичного досвіду й перебудови Я-концепції [11]. Аналіз посттравматичного зростання як ефективного виходу з травми дозволяє виділити ряд ознак ПТЗ. За С. Джозефом, такими показниками $€$ стосунки (люди часто описують, що їхні стосунки покращилися певним способом, приміром, вони стали їх більше цінувати, співчувати іншим); погляд на себе (постраждалі говорять, що набули відчуття власної сили й стійкості, зросла їхня упевненість у собі); життєва філософія (в людей з'являється почуття вдячності за кожен новий прожитий день або відбувається перегляд того, що є насправді важливим для них). Тісно пов'язаними з посттравматичним зростанням $€$ такі змінні: когнітивна оцінка загрози, шкоди й контрольованості ситуації; фокусування на проблемі, прийняття, позитивна реінтерпретація, оптимізм, релігійність, когнітивне опрацювання травматичних спогадів [11]. Зазначена модель описує особистісні трансформації в таких вимірах: зміни в самосприйнятті - нові можливості, персональна стійкість; взаємовідносини; зміни у філософії життя - духовні зміни й життєві цінності.
У вітчизняних дослідженнях інтерес до цього феномену відбитий у наукових працях В.В. Горбунової [1], С.Л. Чачко [6], О.А. Шелюг [7] та інших.

О.А. Шелюг описала алгоритм просування до посттравматичного зростання. Спочатку активується процес автоматичного пригадування травматичної події, у свідомість мимовільно втручаються нав'язливі думки й спогади. У разі подолання дистресу й досягнення певного рівня усвідомлення того, що сталося, автоматичне пригадування поступається місцем рефлексивному переосмисленню травматичного досвіду. Така обробка інформації дозволяє зосередитися на усвідомленні набутого досвіду, з'ясуванні змісту подальшого життя, нового життєвого наративу [7].

У дослідженні С.Л. Чачко проаналізовано, як модифікуються суспільні установки, традиції, норми, цінності в результаті переживань травматичних подій, описано вплив позитивних віддалених психологічних наслідків важких психічних травм на особистість і на збереження та покращення психічного здоров'я особистості, іï соціальної та психологічної адаптації в умовах, що змінюються [10].

Роботи В.В. Горбунової присвячено проблемі відновлення та зростання осіб, які пережили травматичні події. Відзначено роль найближчого оточення в підтримці й фасилітації позитивних змін у картині світу, поведінці постраждалих, розроблені рекомендації особам із найближчого оточення щодо сприяння ПТЗ своїх близьких людей [1].

Аналіз літератури показує, що сформульовано ряд пояснювальних концепцій у цій царині (R.G. Tedeschi й L.G. Calhoun, S. Josef, M. Christopher); ПТЗ стає реальним об'єктом науково-психологічного дослідження (М.Ш. Магомед-Емінов, S.C. Thompson та інші); в емпіричних дослідженнях зібраний великий фактичний матеріал; отримані результати, які дозволяють описати певні закономірності й механізми посттравматичного зростання учасників бойових дій (В.І. Осьодло, Д.С. Зубовський та інші), що дозволяє прогнозувати подальший конструктивний розвиток проблематики $[1 ; 5 ; 9 ; 12]$. Представлено широкий спектр відповідей на питання з проблематики ПТР, описані теоретичні моделі, можливості їхнього застосування в різних умовах. Проведено кроскультурні дослідження ПТЗ, у тому числі щодо когнітивних функцій, формування ідентичності, міжнаціональних і гендерних відмінностей, показано ефективність позитивних впливів на рівні індивіда, групи й суспільства в цілому [12].

Проте існує недостатня кількість психометричних досліджень, в яких наочно була б представлена структура посттравматичного зростання, не можна з упевненістю говорити 
про способи сприяння позитивним змінам для підвищення ефективності заходів психокорекції, реабілітації та психотерапії осіб після впливу психотравмувальної події.

Постановка завдання. На наш погляд, необхідно виявити структуру й особливості змістовних характеристик ПТЗ, дати теоретичне обґрунтування схеми дослідження ПТЗ у підлітків.

Викладосновного матеріалудослідження. Як найважливіша умова конструктивного дослідження ПТЗ, на наш погляд, виступає наявність, а також ступінь вираженості психологічних вимірювань у контексті вікових характеристик. Особливо це актуально щодо підліткового віку.

Р. Тедескі й Л. Калхун вважають, що люди молодого віку будуть більшою мірою схильні до посттравматичного зростання особистості, ніж дорослі й літні люди, чиї когнітивні схеми й захисні механізми стають із віком більш ригідними й важче піддаються змінам [14]. Однак дослідження, присвячені ПТЗ дітей і підлітків, досить нечисленні. Переважно ці дослідження виконані зарубіжними авторами на американській вибірці респондентів (E. Salter, P. Stallard, O. Husson, B. Zebrack та інші) [9; 13]; досліджено ПТЗ китайських дітей і підлітків після землетрусу у Веньчуань [10], норвезьких дітей і підлітків, які постраждали від цунамі 2004 року [12].

Це зумовлює актуальність дослідження ПТЗ підлітків на українській вибірці респондентів. Виходячи із цього, дослідження присвячене пошуку психологічних вимірювань ПТЗ у підлітковому віці.

Підлітковий вік $є$ одним із найяскравіших періодів, відзначених кардинальними змінами практично у всіх сферах життя. Тому можна припустити, що в структурі ПТЗ підлітка вікові характеристики будуть займати важливе місце, що дозволить виявити не тільки їх силу, а й змістовні показники.

У результаті аналізу публікацій із проблеми ПТЗ були виділені психологічні конструкції, пов'язані з позитивною динамікою переживання підлітками психотравмувальної події, які ми визнали можливим об'єднати в такі блоки, базуючись на концепції Р. Тедескі й Л. Калхуна.

Перший блок (умовно названий нами «особистісний») співвідноситься з такими ознаками ПТЗ (за Р. Тедескі й Л. Калхуна), як «особистісне зростання» та «нові можливості», й містить мобілізацію внутрішніх ресурсів, які підвищують самооцінку, змінюють ставлення до себе, роблять підлітка більш рішучим, міцним і відповідальним; загартовується сила волі, проявляються нові здібності.

Другий блок змін («стосунки») відповідає компоненту «ставлення до людей» і вказує на те, що травмувальна подія позитивно впливає на значущі взаємини, зміцнює їх.
Третій блок змін (компоненти «духовне зростання» та «цінності життя» в Р. Тедескі й Л. Калхуна) можна назвати екзистенційним, тому що йдеться про зміну філософії життя та визначення ціннісних пріоритетів у сьогоденні й майбутньому.

Розглянемо детальніше структурні компоненти ПТЗ підлітків.

Особистісний блок. Важливим маркером ПТЗ підлітка можуть бути схеми самості, які виявляються безпосередньо пов'язаними з питаннями самосприйняття та самовідношення.

У теорії соціального пізнання показано, що схеми як узагальнені знання стосуються не тільки об'єктів та явищ навколишнього світу, але також і самих індивідів. Узагальнені знання щодо власної персони отримали назву схеми самості (self-schemas). Один із найвідоміших зарубіжних дослідників теорії схем X. Маркус визначає схеми самості як «засновані на минулому досвіді когнітивні узагальнення людини про себе, що організовують і визначають обробку інформації, пов'язаної з власною персоною (self)» [3, с. 37]. Схеми самості є своєрідними матрицями для організації інформації та побудови власного образу Я, власної Я-концепції. Вони охоплюють значущі уявлення людини про себе [3]. За словами С. Джозефа, навіть коли людина досягає більш розвиненої структури «Я», забезпечує конгруентність між «Я» та досвідом, вона повинна стати більш повноцінно функціональною [11]. У підлітків із ПТЗ буде спостерігатися більш зв'язана Я-концепція, яка містить не тільки усвідомлення персональної сили й опору негативним подіям, а й краще розуміння власної уразливості й власних обмежень.

Підлітковий період відрізняється інтенсивністю процесів індивідуалізації, активним самовизначенням, пошуком власного місця в системі соціальних ролей, розширенням усвідомлення своїх особливостей, здібностей, можливостей для самовираження. Підліток опиняється перед необхідністю безперервного соціального й особистісного самовизначення, «добудовування» свого «Я», пошуку ідентичності. Ідентичність підлітка в разі нормативного ходу розвитку схильна до перетворень, тому вектор дослідження - у визначенні динаміки розвитку й у виявленні змін, що лежать в основі статусів ідентичності. У разі нормативного розвитку ідентичність у різних видах (особистісна, соціальна, соціокультурна, етнічна, громадянська, гендерна, статеворольова, професійна тощо) - це досить усвідомлений та емоційно прийнятий образ себе, що забезпечує можливість адекватного розв'язання життєвих завдань.

У підлітків із ПТЗ образ «я» трансформується в результаті інтеграції елементів особистого досвіду, внаслідок чого набувається 
здатність змінювати свою ідентичність, вибудовувати позитивну ідентичність, яка складається з балансу особистісного й соціального компонентів. Особистісна ідентичність розглядається як сукупність унікальних особистісних характеристик, що дозволяють підтримувати власну цілісність, зберігаючи свободу вибору й відкритість новому досвіду. Соціальна ідентичність підлітка - система уявлень про соціальну реальність, узгоджених з очікуваннями й нормами соціального середовища, за наявності власної активної позиції в освоєнні соціальних ролей, пошуку референтної групи, що дозволяє зайняти певне місце в суспільстві.

Особистісна ідентичність вибудовується в результаті проходження криз і базується на основі виходу з них. Травмувальна подія в житті підлітка постає як так звана точка біфуркації, потрапляючи в яку, особистість підлітків зазнає ті чи інші можливі зміни: або примножуються ії сили, компетенції для подальшого життєвого шляху, або такий етап не пройдений та ускладнює її розвиток; відповідно, в підлітків із ПТЗ передбачається досягнення позитивної ідентичності. Л.Б. Шнейдер встановлено, що репрезентацією досягнутої позитивної ідентичності $€$ «позитивне самовідношення під час позитивного оцінювання власних якостей і стабільного зв'язку із соціумом, а також повної координації механізмів ідентифікації та відокремлення» [8, с. 43]. Нею визначені критерії позитивної ідентичності, серед яких висока самоцінність і цінність свого «Я» для інших, підвищена рефлексія, усвідомлення труднощів, висока активність дієвості й спілкування [8].

Важливе доповнення до усвідомлення власної ідентичності - усвідомлення підлітком часу свого існування, тому наступним виміром ПТЗ підлітків, на наш погляд, може виступати тимчасова перспектива. Сприйняття та осмислення минулого, сьогодення та майбутнього відіграють детерміновану роль у поведінці людини, виступають як його «орієнтовна основа».

Одна $з$ найбільш значущих проблем, на думку Д.О. Леонтьєва [4], полягає в з'ясуванні того, коли й на підставі яких передумов, за яких умов людина виявляє себе в часі. Іншими словами, чим саме ті, що живуть у часі, тобто вміють вибудувати тимчасову перспективу, відрізняються психологічно від тих, що живуть поза часом, тобто не володіють цими навичками. Жити в часі означає відчувати себе в процесі переходу з минулого через сьогодення в майбутнє [4]. Поза часом живуть ті, хто не може інтегрувати минуле, сьогодення та майбутнє в єдиний процес зустрічної зміни себе й світу.

Для підлітків важливе не тільки усвідомлення минулого, сьогодення та майбутнього в їх єдності й цілісності, але й вміння пере- осмислювати вже сформовану тимчасову перспективу й створювати нову модель майбутнього.

На підставі таких критеріїв, як цілісне сприйняття часу / фіксація на певному часовому відрізку й ставлення підлітків до минулого, сьогодення та майбутнього, виділяються такі групи підлітків за умови нормативного ходу розвитку: 1) реально сприймають дійсність, вважають за краще жити в теперішньому часі, усвідомлюють єдність минулого, сьогодення та майбутнього; 2) сприймають час у всій його єдності, їх відмінні риси - здатність жити «тут і зараз» у поєднанні зі спрямованістю в майбутнє; 3) перебувають в ілюзорному, нереалістичному майбутньому; 4) орієнтуються лише на один відрізок тимчасової шкали - єдине «сьогодення - майбутнє»; 5) фіксуються на щасливому й комфортному минулому [2].

Ймовірно, що особливості вибудовування часової перспективи можуть розглядатися як одна з діагностичних ознак у підлітків, які пережили психічну травму. Ми припускаємо, що підлітки, які мають фіксацію на негативному минулому й сприймають майбутнє як безперспективне, швидше будуть перебувати в стані, близькому до ПТСР; підлітки, орієнтовані на «тут і зараз», повернулися до нормативного ходу розвитку, переживши травму; в підлітків, які сприймають майбутнє як перспективне, за умови цілісного сприйняття свого психологічного минулого, сьогодення та майбутнього, уміння жити в сьогоденні й планувати своє майбутнє можливе посттравматичне зростання.

З огляду на вік, ці підлітки далеко не завжди мають ясну й чітку картину свого майбутнього; загострене почуття незворотності часу поєднується з уявленням, ніби час має здатність зупинятися. Це приводить до того, що підлітки самі починають планувати своє майбутнє, але часто ця діяльність має несистематичний характер, а надії, проєкти, прагнення, пов'язані з майбутнім, вимагають усвідомленості й серйозної рефлексивної роботи.

Ми вважаємо можливим розглядати рефлексію як одне з психологічних вимірювань ПТЗ підлітків. Щоб рухатися до посттравматичного зростання, людина повинна пройти через етап інтенсивної рефлексії. Саме ця здатність до рефлексії дозволяє йти далі, радіти життю, незважаючи на наявність трагічних подій у минулому. Слід враховувати диференціацію рефлексії на підставі її спрямованості. Виділяють два типи рефлексії, що умовно позначаються як «інтрапсихічна» й «інтерпсихічна» рефлексія. Перша співвідноситься зі здатністю до самосприйняття змісту своєї власної психіки та його аналізу, друга - зі здатністю до розуміння психіки інших людей, що містить як здатність «встати на місце іншого», так і механізми проєкції, ідентифікації, емпатії, 
тобто властивості, пов'язані зі ставленням до інших людей.

Другий блок вимірювань ПТЗ пов'язаний із відносинами з друзями й однолітками, спілкуванням із дорослими (батьками й іншими родичами, вчителями). Інтимно-особистісне спілкування з однолітками є провідною діяльністю цього періоду. У відносинах з однолітками для підлітків, з одного боку, характерно розширення взаємодії для задоволення потреби пережити новий досвід, випробувати себе в новій ролі дорослого, рівноправного партнера у відносинах. 3 іншого боку, характерна вибірковість у дружніх прихильностях, що задовольняє потребу в розумінні. Значущою сферою стають взаємини з протилежною статтю. Відносини 3 однолітками більш значущі, ніж відносини з дорослими. У цей період для підлітка важливо стати автономним щодо батьків. Але в підлітків із ПТЗ, на нашу думку, налагоджуються взаємини 3 близькими, сімейні зв'язки починають цінуватися вище; у відносинах із батьками вони прагнуть не тільки отримувати (турботу, емоційну підтримку, допомогу), а й віддавати.

У підлітків із ПТЗ позитивні індикатори міжособистісної взаємодії можуть проявлятися в ставленні до літніх людей. На жаль, більшість підлітків скептично оцінює значущість життевої мудрості, проникливості й досвіду літніх людей, у них часто спостерігається феномен ейджизму, що розглядається як принижувальне ставлення до людини через його вік; їм буває важко прийняти особливості поведінки літніх людей, навіть близьких - бабусь чи дідусів.

Пережита травма може стати однією з реальних можливостей вирощування «людського в людині» (В.І. Слободчиков). З'являється бажання зробити щось для тих, у кого вже немає надії, допомогти тяжкохворим і самотнім людям у такому похилому віці, коли їх вже мало що радує в житті. Ставлення до людей похилого віку, важко хворих, безпорадних людей, дітей, тварин є випробуванням людяності, має діяльнісний характер: це прояв уваги, посильна допомога, турбота, врахування інтересів, чуйність, ввічливість, делікатність у спілкуванні.

Третя сфера прояву посттравматичного зростання - це поява більш інтегрованої життєвої філософії, світогляду, включаючи підвищення значущості власного існування, зміну пріоритетів, зміцнення переконань, почуття сенсу, повне оновлення світосприйняття [6]. Екзистенційний блок вимірювань ПТЗ у підлітків може містити такі показники, як переоцінка цінностей, визначеність життєвих орієнтирів, узгодженість власних ціннісних уявлень і цінностей значущих дорослих (батьки, педагоги), трансформація смислів. Ці позитивні зміни виражаються в зміні життєвих пріоритетів, умінні цінувати життя в цілому й у дрібницях, можливості відрізняти дійсно важливі речі від дрібниць, наявності яскравих позитивних орієнтирів і зрозумілих алгоритмів досягнення соціально схвалюваного успіху, розумінні того, що немає таких обставин і ситуацій, в яких людське життя втратило б свій сенс.

Висновки з проведеного дослідження. Отримані результати теоретичних розвідок узгоджуються з основними характеристиками підліткового віку, прийнятими у вітчизняній психології розвитку. У такому випадку модель ПТЗ підлітків може бути розглянута як уявлення про конкретний віковий етап, що реалізуються під час переживання підлітком психотравми. Було виділено три базових блоки ПТЗ підлітків: особистісний блок (схеми самості, які формують Я-концепцію та ідентичність особистості, часова перспектива, рефлексія); блок відносин (більш зріли відносини з людьми, емпатія) та екзистенціальний блок (духовне зростання, зміна філософії життя, ціннісно-смислових орієнтацій). Підсумком ПТЗ $€$ формування позитивної ідентичності, нової життєвої перспективи, трансформація цінностей і зміни відносин із людьми. Подальші перспективи пов'язані з емпіричною перевіркою такої моделі, яка дозволяє визначити не тільки рівень ПТЗ, а і його зміст і структуру, а також специфіку в різних життєвих обставинах.

\section{ЛITEPATУРA:}

1. Горбунова В.В. Сприяння соціального оточення відновленню та зростанню особистості при посттравматичних станах та розладах. Наука і освіта. Психологія. 2016. № 5. С. 40-45.

2. Кузнецова О.В. Роль временной перспективы в личностном и профрессиональном самоопределении подростков. Психологическая наука и образование. 2007. Том. 12. № 3. С. 5-15.

3. Курышева О.В. Возрастные схемы самости подростков. Вестник Российского университета дружбы народов. Серия: Психология и педагогика. 2013. № 3. C. 37-43.

4. Леонтьев Д.А. О времени: иллюзия ответов. Экзистенциальная традиция: философрия, психология, психотерапия. 2004. № 1. С. 113-118.

5. Осьодло В.І., Зубовський Д.С. Посттравматичне зростання особистості учасників бойових дій: сучасний стан та перспективи. Український психологічний журнал. 2017. Вип. 1. С. 63-79.

6. Чачко С.Л. Психічна травма і посттравматичне зростання особистості як чинники соціальних змін. Наукові студії із соціальної та політичної психології. 2011. № 26. С. 268-276.

7. Шелюг О.А. Багатовимірність френомену посттравматичного росту: біологічний, психологічний та соціокультурний складники особистісних транссормацій. Психологія і особистість. 2014. № 1. С. 112-129.

8. Шнейдер Л.Б. Личностная, гендерная и профессиональная идентичность: теория и методы диагностики. Москва : МПСИ, 2007. 128 с. 
9. Husson O., Zebrack B., Block R., Embry L., Aguilar C., Hayes-Lattin B., Cole S. Posttraumatic growth and well-being among adolescents and young adults (AYAs) with cancer: A longitudinal study. Support Care Cancer. 2017. № 25. P. 2881-2890.

10. Jieling C., Xinchun W. Post-traumatic stress symptoms and post-traumatic growth among children and adolescents following an earthquake: a latent profile analysis. Child Adolesc Mental Health. 2017. Vol. 22 (1). P. 23-29.

11. Joseph S. Growth Following Adversity: Positive Psychological Perspectives on Posttraumatic
Stress. Psychological Topics. 2009. Vol. 18 (2). P. 335-344.

12. Kanako Taku, Richard G. Tedeschi, Lawrence G. Calhoun, Jane Shakespeare-Finch. Posttraumatic Growth: Theory, Research and Applications. Routledge, 2018. 256 p.

13. Salter E., Stallard P. Posttraumatic growth in child survivors of a road traffic accident. Journal of Traumatic Stress. 2004. Vol. 17. P. 335-340.

14. Tedeschi R.G., Calhoun L.G. Posttraumatic growth: Conceptual foundations and empirical evidence. Psychological Inquiry. 2004. Vol. 15. P. 1-18. 